\title{
Analisis Aerodinamika Bodi Mobil Hemat Energi Kelas Urban Menggunakan Computational Fluid Dynamics
}

\author{
Glaudius Alexander Vajra*, Sheila Tobing, Isdaryanto Iskandar \\ Program Studi Teknik Mesin, Fakultas Teknik, Universitas Katolik Indonesia Atma Jaya \\ BSD City, Jalan Raya Cisauk, Desa Sampora, Kec. Cisauk, Kab. Tangerang, Banten, 15435 \\ *E-mail: alex.vajra@gmail.com
}

Diterima: 30-03-2021; Direvisi: 02-08-2021; Dipublikasi: 27-08-2021

\begin{abstract}
Abstrak
Kontes Mobil Hemat Energi (KMHE) merupakan kompetisi nasional yang diselenggarakan setiap tahun untuk menguji kemampuan merancang dan mengompetisikan kendaraan yang ramah lingkungan. Sejak tahun 2017, Universitas Katolik Indonesia Atma Jaya secara rutin mengikuti kompetisi ini melalui Workshop Mesin UNIKA Atma Jaya (WSM) pada kategori Urban. Penelitian ini bertujuan untuk menghasilkan desain bodi yang aerodinamis dengan target nilai koefisien gaya hambat lebih rendah dari $0,35\left(C_{D}<0,35\right)$. Penelitian dilakukan menggunakan simulasi CFD pada software ANSYS v17.2. Perancangan bodi dimulai dengan membuat desain base model untuk menyesuaikan dengan regulasi KMHE 2019 serta sasis dan komponen kelistrikan yang baru. Modifikasi desain base model dilakukan untuk mencapai target nilai $C_{D}$. Modifikasi yang dilakukan berupa penambahan spoiler, membuat coakan pada bagian bawah di sisi belakang kendaraan dan memperhalus sudut tajam pada desain bodi. Modifikasi tersebut menghasilkan desain bodi dengan nilai $C_{D}$ rata-rata sebesar 0,295183 yang akan digunakan oleh tim WSM untuk menghadapi KMHE 2021.
\end{abstract}

Kata kunci: aerodinamis; CFD; KMHE; koefisien gaya hambat

\begin{abstract}
Kontes Mobil Hemat Energi (KMHE) is a national student competition that held annually to test the ability to design and build environmentally friendly vehicles. Since 2017, Atma Jaya Catholic University of Indonesia has regularly participated in this competition through Workshop Mesin of UNIKA Atma Jaya (WSM) in the Urban category. This research aims to produce an aerodynamic body design with a target of drag coefficient below $0,35\left(C_{D}<0,35\right)$. The research is conducted using CFD simulations on ANSYS v17.2 software. The research begins with designing the base model to comply with the regulations of 2019 KMHE as well as the new chassis and electrical components. Modification of the base model is done to achieve the targeted $C_{D}$ value. The modifications done to the base model are the addition of a spoiler, the incorporation of slope at the bottom rear side of the vehicle and the smoothing of sharp corners. These modifications resulting in a body design with an average $C_{D}$ value of 0,295183 which will be used by WSM to participate in KMHE 2021.
\end{abstract}

Keywords: aerodynamics; CFD; KMHE; drag coefficient

\section{Pendahuluan}

Kontes Mobil Hemat Energi (KMHE) merupakan kompetisi tahunan yang diadakan oleh Direktorat Jenderal Pendidikan Tinggi untuk menguji kemampuan merancang dan mengompetisikan kendaraan yang irit, aman dan ramah lingkungan [1]. Pada perlombaan ini, terdapat 2 kategori kendaraan yang diperlombakan, yaitu Prototype dan Urban. Prototype merupakan kategori dengan konsep kendaraan masa depan yang didesain khusus untuk mengoptimalkan aspek aerodinamika. Sedangkan Urban merupakan kategori yang memperlombakan kendaraan roda empat yang tampilannya menyerupai kendaraan pada umumnya dan sesuai untuk berkendara di jalan umum [2]. Kegiatan ini diikuti oleh berbagai universitas dari seluruh Indonesia setiap tahunnya. Salah satunya ialah Universitas Katolik Indonesia Atma Jaya, melalui Workshop Mesin UNIKA Atma Jaya (WSM). Tim Workshop Mesin UNIKA Atma Jaya telah mengikuti kompetisi ini secara rutin sejak tahun 2017. Namun selama 3 tahun mengikuti KMHE, tim WSM belum pernah mengikuti race akibat adanya masalah pada mobil. Tim WSM berencana untuk merancang bodi yang baru untuk 
KMHE 2021, di mana bodi harus mempunyai desain yang aerodinamis untuk mengurangi gaya hambat mobil. Semakin aerodinamis sebuah bodi, maka semakin rendah juga nilai gaya hambat [3].

\section{Material dan metodologi}

Metode yang akan digunakan pada penelitian ini ialah metode komputasi Finite Volume Method (FVM) untuk mengetahui fenomena aerodinamika pada bodi mobil hemat energi kategori Urban secara 3 dimensi (3D), dengan menggunakan software ANSYS v17.2 untuk mengetahui desain bodi dengan nilai $C_{D}$ terendah. Penelitian diawali dengan proses validasi, proses ini dilakukan untuk memeriksa akurasi solver dan setup pada software yang digunakan agar mendapatkan data yang akurat [4]. Metode validasi yang dilakukan ialah dengan cara membandingkan data hasil simulasi model validasi dengan data literatur yang menggunakan model yang sama. Validasi data dikatakan berhasil apabila galat antara data hasil simulasi dengan data literatur kurang dari sama dengan 10\%. Model validasi yang digunakan ialah Ahmed Body, yaitu sebuah model bodi mobil yang bentuknya disederhanakan untuk mengetahui simulasi aliran udara pada bodi tersebut yang diciptakan oleh Ahmed et. al., [5]. Literatur yang digunakan pada proses validasi ini ialah pengujian CFD Ahmed Body yang dilakukan oleh Saurabh Banga et. al., [6]. Bentuk dari Ahmed Body dapat dilihat pada Gambar 1.
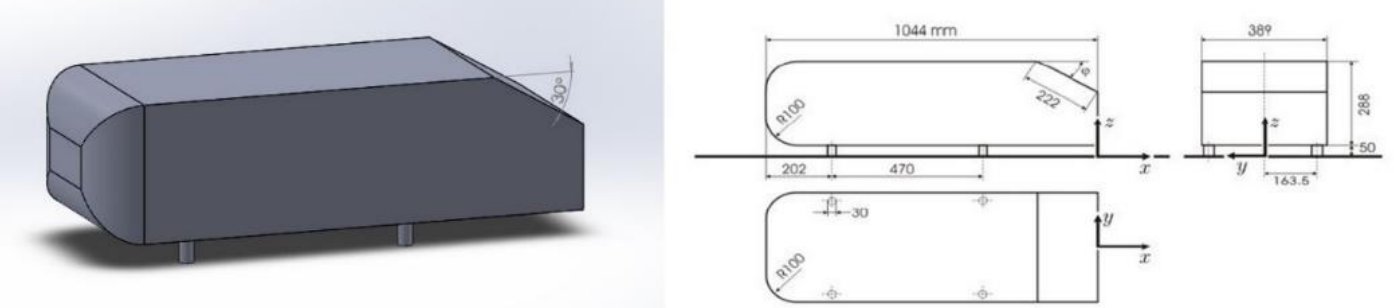

Gambar 1. Bentuk dan dimensi model validasi Ahmed Body

Tahap selanjutnya ialah membuat desain base model untuk simulasi. Pembuatan desain base model mengacu kepada regulasi teknis KMHE 2019 kategori Urban [7]. Pembuatan desain base model juga menyesuaikan dengan sasis baru dan komponen kelistrikan baru yang dirancang oleh sesama mahasiswa. Dimensi dari bodi harus menyesuaikan sasis karena nantinya bodi akan menempel pada sasis. Berdasarkan beberapa kompromi dari regulasi teknis, dimensi sasis dan komponen kelistrikan, maka terciptalah desain base model (Gambar 2). Untuk mendapatkan nilai $C_{D}$ terendah, modifikasi desain akan dilakukan pada base model. Proses modifikasi dan simulasi model hasil modifikasi dilakukan terus hingga mendapatkan nilai $C_{D}<0,35$.
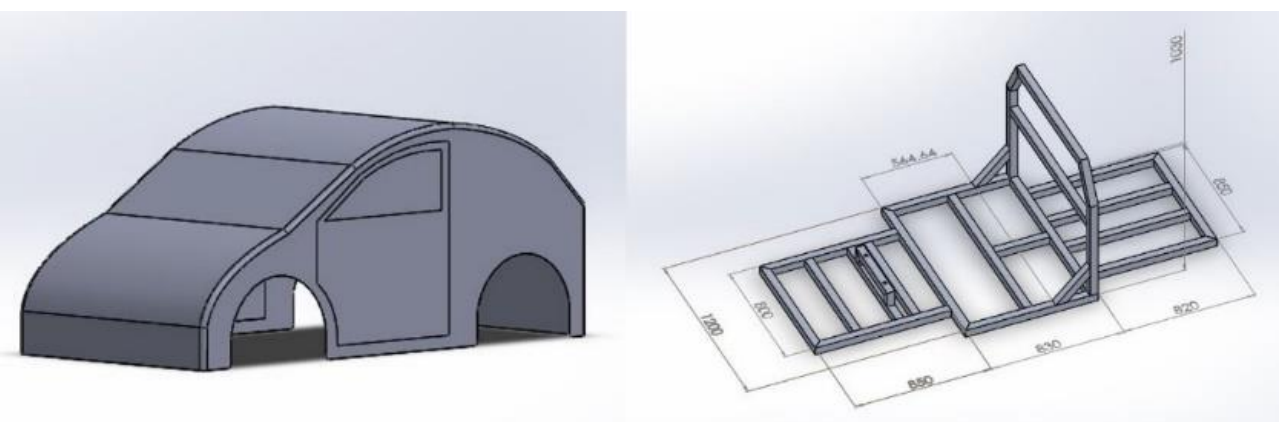

Gambar 2. Desain base model dan dimensi sasis

\section{Hasil dan pembahasan}

\subsection{Hasil Validasi}

Proses validasi pada penelitian ini dilakukan menggunakan model Ahmed Body dengan variasi slant angle $0^{\circ}$ hingga $30^{\circ}$. Seluruh settings dan ketentuan yang digunakan pada simulasi untuk validasi mengikuti jurnal referensi [6]. 
Glaudius Alexander Vajra dkk /Jurnal Rekayasa Mesin

p-ISSN: 1411-6863, e-ISSN: 2540-7678

Vol.16|No.2|210-217|Agustus|2021

Berdasarkan penjabaran Tabel 1, dapat diketahui bahwa rata-rata error atau galat antara simulasi dengan literatur berada di bawah 10\%, sehingga validasi yang dilakukan pada penelitian ini sudah memenuhi syarat galat $<10 \%$.

Tabel 1. Hasil validasi Ahmed Body

\begin{tabular}{ccccccc}
\hline \multicolumn{7}{c}{ Hasil Validasi Ahmed Body } \\
Sudut & $C_{D}$ Validasi & $C_{L}$ Validasi & $C_{D}$ Literatur & $C_{L}$ Literatur & $\begin{array}{c}\text { Error } \\
C_{D}\end{array}$ & $\begin{array}{c}\text { Error } \\
C_{L}\end{array}$ \\
\hline 0 & 0,251199 & $-0,126096$ & 0,250031 & $-0,117447$ & $0,47 \%$ & $7,36 \%$ \\
5 & 0,23475971 & $-0,01378892$ & 0,237215 & $-0,0149709$ & $1,04 \%$ & $7,90 \%$ \\
7.5 & 0,23669101 & 0,027585213 & 0,234631 & 0,0292149 & $0,88 \%$ & $5,58 \%$ \\
10 & 0,23967733 & 0,076716692 & 0,236738 & 0,082971 & $1,24 \%$ & $7,54 \%$ \\
12.5 & 0,24206084 & 0,12644915 & 0,241644 & 0,132483 & $0,17 \%$ & $4,55 \%$ \\
15 & 0,24816913 & 0,17300937 & 0,246833 & 0,185001 & $0,54 \%$ & $6,48 \%$ \\
20 & 0,26446922 & 0,28262219 & 0,261934 & 0,283622 & $0,97 \%$ & $0,35 \%$ \\
30 & 0,30259895 & 0,37064082 & 0,297872 & 0,347783 & $1,59 \%$ & $6,57 \%$ \\
& & & & Rata-rata Error & $\mathbf{0 , 8 6 \%}$ & $\mathbf{5 , 7 9 \%}$ \\
\hline
\end{tabular}

\subsection{Simulasi Base Model}

Simulasi CFD pada penelitian ini diawali dengan melakukan simulasi pada desain base model. Model yang dibuat untuk disimulasikan sedikit berbeda dengan model yang terdapat pada Gambar 2. Untuk simulasi, bagian roda perlu disederhanakan bentuknya. Hal ini dilakukan karena sub-software ANSYS, yaitu DesignModeler tidak dapat memproses bentuk roda yang cukup kompleks yang dibuat pada Solidworks. Wujud desain base model yang sudah disederhanakan dapat dilihat pada Gambar 3.

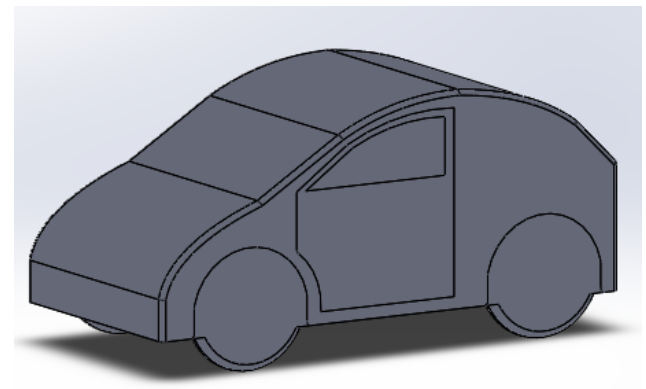

Gambar 3. Desain base model untuk simulasi

Setelah geometry model selesai dibuat, file tersebut akan diimpor ke dalam DesignModeler untuk membuat domain menggunakan fitur enclosure. Sama seperti saat validasi, domain ini akan diberi fitur Boolean untuk membuat rongga berbentuk desain mobil pada domain tersebut. Selanjutnya ialah meshing. Proses meshing dilakukan pada seluruh domain beserta desain mobil. Tahapan meshing yang dilakukan ialah global mesh, face sizing, inflation dan body sizing. Meshing yang dilakukan menghasilkan 5.714 .448 elemen. Bentuk dari domain dan hasil dari proses meshing

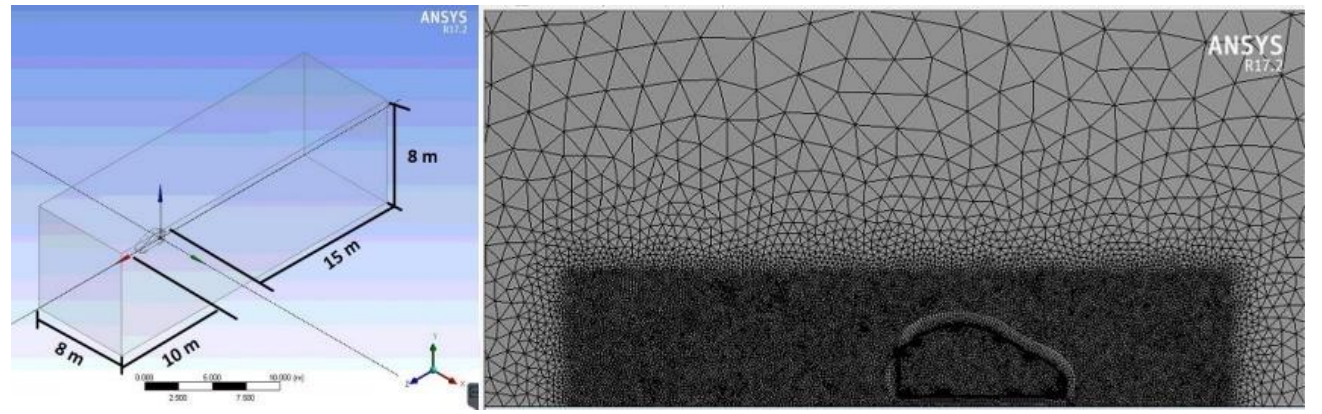

Gambar 4. 


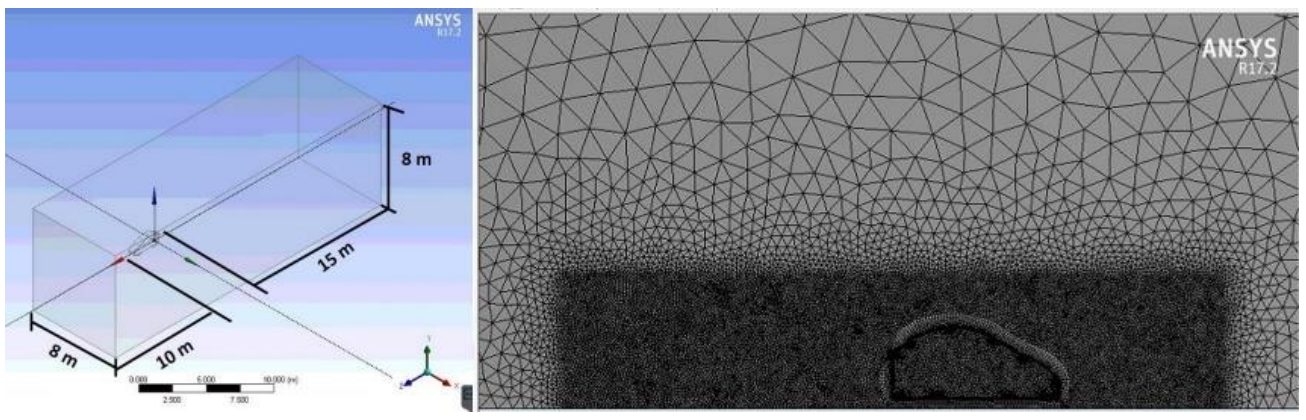

Gambar 4. Domain dan hasil meshing

Langkah selanjutnya ialah melakukan setup untuk mempersiapkan komputasi. Ketentuan setup yang digunakan adalah:

- Model aliran: realizeable k-E, enhanced wall function untuk near wall treatment. Penggunaan model aliran ini memungkinkan untuk mendapatkan hasil yang akurat dan stabil dalam waktu yang relatif cepat [8].

- Fluida: udara $\left(\rho=1,225 \mathrm{~kg} / \mathrm{m}^{3}\right)$, Dynamic viscosity $(\mu): 1,789 \times 10^{-5} \mathrm{~kg} / \mathrm{ms}$.

- Solution method: coupled untuk pressure-velocity coupling scheme, least squared cell based untuk gradient, standard untuk pressure, momentum, turbulence kinetic energy dan turbulence dissipation rate menggunakan second order upwind.

- Kecepatan: $2,78 \mathrm{~m} / \mathrm{s}(10 \mathrm{~km} / \mathrm{jam})$, Turbulence Intensity: $1 \%$ pada inlet

- Frontal area: 0,6409335 $\mathrm{m}^{2}$. Nilai frontal area didapatkan menggunakan fitur Projected Areas pada ANSYS Workbench untuk menghitung area yang terpapar oleh aliran udara.

- Komputasi dilakukan sebanyak 1000 iterasi dengan batas residual sebesar $10^{-3}$.

Tabel 2. Hasil simulasi desain base model

\begin{tabular}{cccc}
\hline Desain & $\boldsymbol{C}_{\boldsymbol{D}}$ Total & $\boldsymbol{C}_{\boldsymbol{D}}$ Pressure & $\boldsymbol{C}_{\boldsymbol{D}}$ Skin Friction \\
\hline Base Model & 0,38178 & 0,34108972 & 0,040690418 \\
\hline
\end{tabular}

\section{Berdasarkan}

Tabel 2, dapat diketahui bahwa nilai $C_{D}$ total yang didapat untuk desain base model sebesar 0,38178 . Nilai $C_{D}$ yang didapat masih berada di atas target yang ditentukan, sehingga modifikasi akan dilakukan untuk menurunkan nilai $C_{D}$.

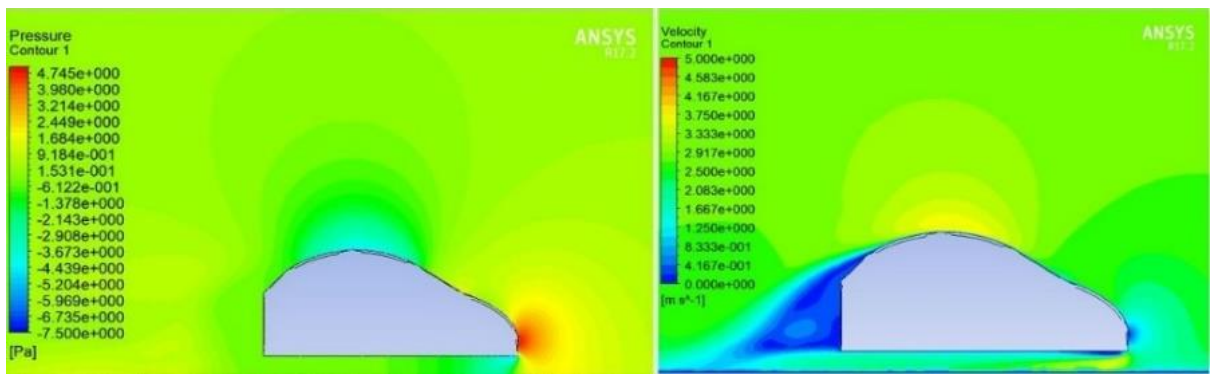

Gambar 5. Kontur tekanan dan kecepatan simulasi base model

Pada Gambar 5 sebelah kanan, dapat diketahui bahwa aliran pada bagian belakang mobil mengalami fenomena separasi yang menyebabkan gaya hambat bertambah. Selain itu, perbedaan tekanan pada bagian depan kendaraan pada titik stagnasi (kontur berwarna merah) dan bagian belakang kendaraan pada titik separasi (kontur berwarna biru) menyebabkan pressure drag sehingga gaya hambat semakin meningkat. Akibat adanya fenomena separasi, dapat dilihat 
pada bagian belakang mobil terdapat fenomena wakes, yang merupakan salah satu penyebab terciptanya gaya hambat [9]. Untuk menurunkan koefisien gaya hambat $\left(C_{D}\right)$ dari desain bodi, maka area wakes tersebut harus diperkecil [10].

\subsection{Simulasi Modifikasi 1}

Berdasarkan hasil simulasi desain base model, dapat diketahui bahwa diperlukan perbaikan desain pada bagian belakang kendaraan untuk menurunkan $C_{D}$. Modifikasi yang dibuat berupa spoiler (sayap belakang) dan coakan pada bagian bawah bodi mobil (Gambar 6 kanan). Kedua modifikasi ini dibuat dengan tujuan untuk memperkecil area wakes pada bagian belakang kendaraan agar menurunkan gaya hambat. Modifikasi yang dibuat tidak merubah dimensi lebar dan tinggi dari desain base model, sehingga nilai frontal area yang digunakan juga sama dengan simulasi desain base model, yaitu $0,6409335 \mathrm{~m}^{2}$.

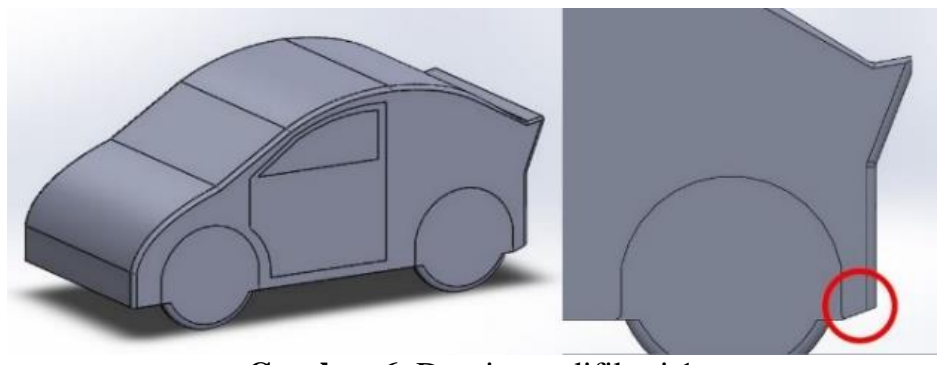

Gambar 6. Desain modifikasi 1

Tabel 3. Perbandingan desain base model dan modifikasi 1

\begin{tabular}{cccc}
\hline Desain & $\boldsymbol{C}_{\boldsymbol{D}}$ Total & $\boldsymbol{C}_{\boldsymbol{D}}$ Pressure & $\boldsymbol{C}_{\boldsymbol{D}}$ Skin Friction \\
\hline Base Model & 0,38178 & 0,34108972 & 0,040690418 \\
Modifikasi 1 & 0,357235 & 0,31463729 & 0,042597858 \\
\hline
\end{tabular}

Berdasarkan Tabel 3, dapat diketahui bahwa $C_{D}$ mengalami penurunan sebesar 6,429\%. Penurunan ini dapat terjadi karena pressure drag yang terjadi pada desain mobil mengalami penurunan. Pada sisi lain, skin friction drag mengalami kenaikan meskipun tidak signifikan. Namun besarnya nilai $C_{D}$ belum sesuai dengan target, sehingga akan dilakukan modifikasi kembali.

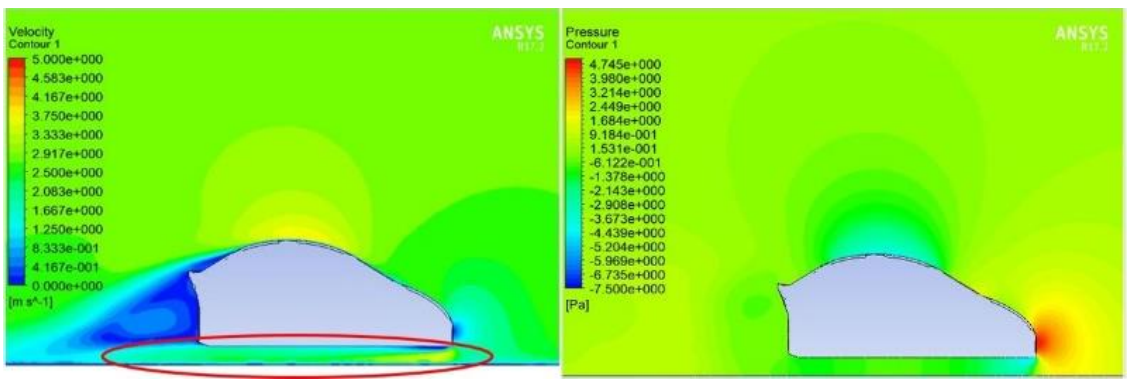

Gambar 7. Kontur kecepatan dan tekanan desain modifikasi 1

Pada Gambar 7 kiri, dapat diketahui bahwa area wakes yang terdapat pada bagian belakang mobil sudah mengecil meskipun tidak terlalu signifikan. Coakan pada bagian bawah desain modifikasi 1 cukup berpengaruh pada aliran udara di bagian bawah kendaraan. Kondisi ini dapat dilihat pada kontur berwarna hijau di bagian bawah mobil yang areanya lebih luas daripada desain base model. Hal ini menunjukkan aliran udara pada bagian bawah kendaraan ikut andil berperan dalam koefisien gaya hambat yang dihasilkan pada sebuah kendaraan. Pada Gambar 7 kanan, dapat dilihat pada bagian depan kendaraan terdapat kontur area kuning antara bonnet dan windshield. Hal ini menunjukkan adanya tekanan yang cukup besar pada sambungan tersebut akibat aliran udara yang menabrak sudut yang cukup tajam. 
Glaudius Alexander Vajra dkk /Jurnal Rekayasa Mesin

p-ISSN: 1411-6863, e-ISSN: 2540-7678

Vol.16|No.2|210-217|Agustus|2021

Kondisi ini menyebabkan aliran udara seakan "lepas" dari bodi mobil, kemudian "menempel" kembali pada bagian tengah windshield. Kondisi ini dinamakan dengan laminar bubble. Kondisi ini umumnya terjadi pada saat kendaraan melaju pada kecepatan rendah dan dapat menghilang seiring dengan bertambahnya kecepatan, namun apabila bentuk ini tetap dipertahankan, ada kemungkinan terjadinya separasi aliran yang lebih besar sehingga dapat meningkatkan nilai $C_{D}$ pada mobil [11].

\subsection{Simulasi Modifikasi 2}

Bagian depan kendaraan berpengaruh cukup besar dalam besarnya drag coefficient yang dihasilkan, terutama pada bagian bumper dan bonnet. Sudut sudut yang tajam juga dapat menyebabkan terjadinya separasi aliran pada sekitar kendaraan yang menyebabkan terjadinya gaya hambat [10]. Modifikasi kedua (
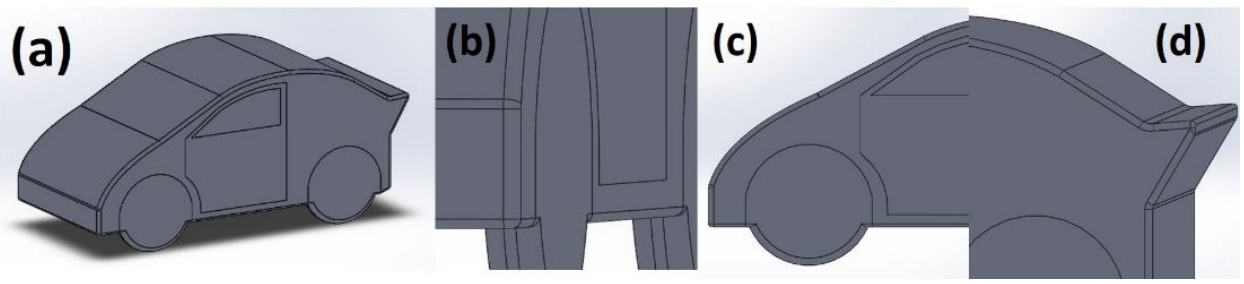

Gambar 8) yang dilakukan mengacu kepada kedua hal tersebut. Modifikasi desain yang dilakukan berupa perubahan bentuk bonnet yang lebih tinggi agar mengurangi sudut tajam antara bonnet dengan windshield (
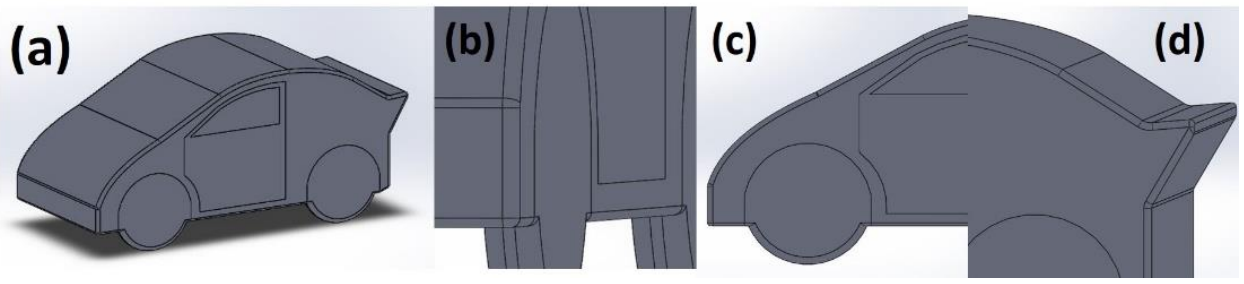

Gambar

$$
\text { 8c), }
$$

$$
\text { memperhalus }
$$

sudut

tajam

$$
\text { pada }
$$

bagian

bawah

kendaraan
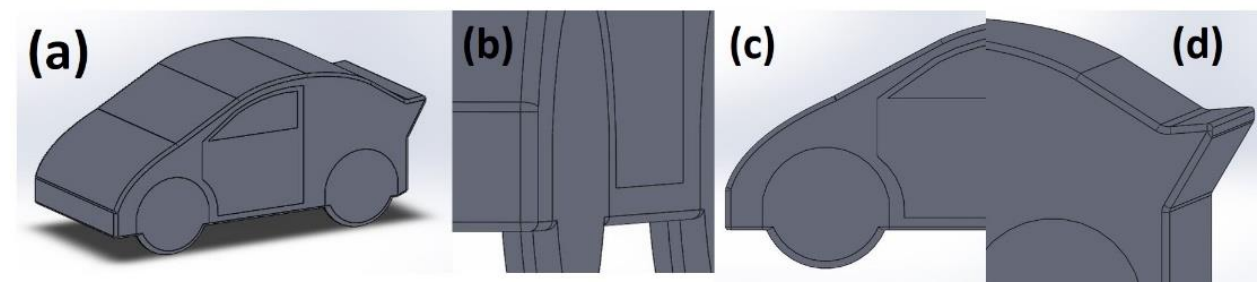

Gambar

$8 \mathrm{~b})$

dan

pada

spoiler

di

bagian

belakang
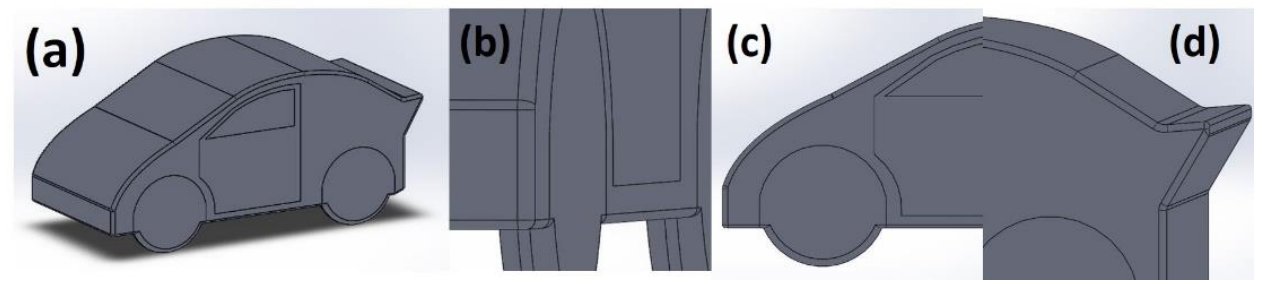

Gambar 8 d). Pengaturan setup yang dilakukan dan besar frontal area yang digunakan juga sama dengan simulasi modifikasi 1. 

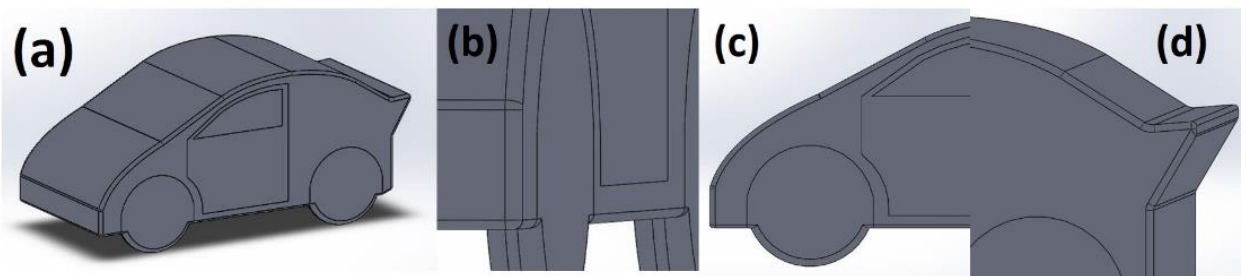

Gambar 8. (a) Desain modifikasi 2, (b) detail refine edges, (c) desain bonnet dan (d) refine edges pada spoiler

Tabel 4. Perbandingan desain base model dengan desain modifikasi 1 dan 2

\begin{tabular}{cccc}
\hline Desain & $C_{D}$ Total & $C_{D}$ Pressure & $C_{D}$ Skin Friction \\
\hline Base Model & 0,38178 & 0,34108972 & 0,040690418 \\
Modifikasi 1 & 0,357235 & 0,31463729 & 0,042597858 \\
Modifikasi 2 & 0,32251 & 0,27701904 & 0,04594592 \\
\hline
\end{tabular}

Berdasarkan

Tabel 4, dapat diketahui bahwa nilai $C_{D}$ mengalami penurunan yang disebabkan oleh turunnya pressure drag. Di sisi lain, skin friction drag mengalami peningkatan yang menandakan bahwa aliran udara lebih "menempel" pada bodi kendaraan. Dengan ini, dapat dikatakan bahwa desain modifikasi 2 memiliki desain yang lebih streamline dibandingkan dengan desain modifikasi 1 dan desain base model. Desain yang lebih streamline dapat diartikan aliran udara yang melewati desain mobil cenderung mengarah pada attached flow [12]. Hal ini didukung dengan teori yang mengatakan bahwa separated flow dapat meningkatkan nilai $C_{D}$ yang terjadi dan apabila benda memiliki desain yang lebih streamline, proporsi skin friction drag akan meningkat dan pressure drag akan menurun [13].

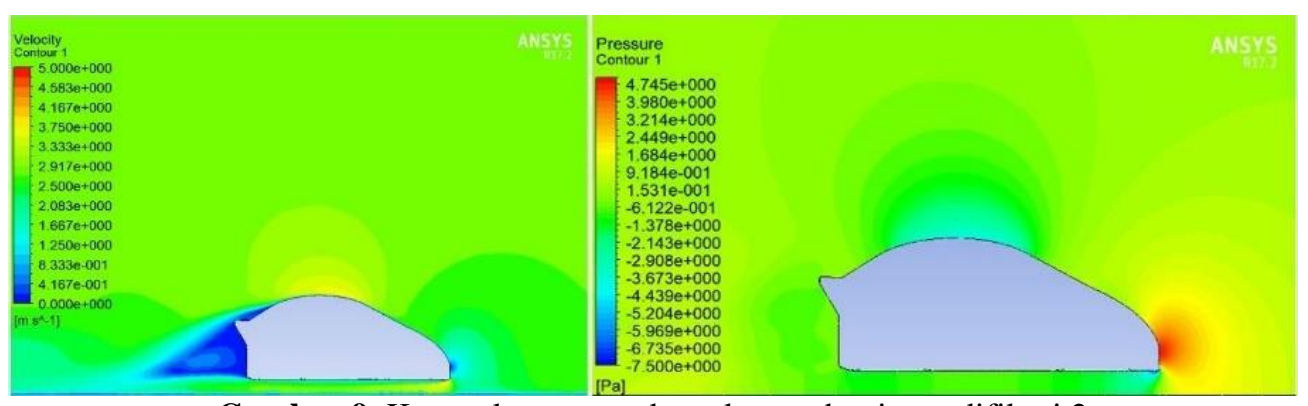

Gambar 9. Kontur kecepatan dan tekanan desain modifikasi 2

Berdasarkan Gambar 9 kiri, dapat diketahui bahwa area wakes yang muncul pada bagian belakang kendaraan sudah semakin mengecil bila dibandingkan dengan desain modifikasi 1. Area wakes yang lebih kecil ini menyebabkan berkurangnya gaya hambat yang terjadi pada bagian belakang mobil, sehingga nilai pressure drag juga ikut turun. Aliran udara pada bagian bawah kendaraan memiliki kecepatan yang didominasi oleh kontur berwarna hijau. Hal ini menandakan kecepatan aliran udara pada bagian bawah kendaraan sudah lebih seragam akibat perbaikan sudut tajam pada sisi bawah kendaraan.

Pada Gambar 9 kanan, dapat dilihat bahwa perbaikan desain pada bagian bonnet menyebabkan hilangnya kontur berwarna kuning pada sambungan bonnet dengan windshield. Hal ini menyebabkan aliran udara yang melewati permukaan bodi tetap "menempel" pada permukaan bodi sehingga fenomena separasi tidak terjadi, yang mengakibatkan meningkatnya nilai skin friction drag. Titik stagnasi yang ditandai dengan kontur berwarna merah pada ketiga desain mobil memiliki tekanan yang besarnya sama, yaitu sekitar 4,7 Pa. Hal ini disebabkan karena ketiga desain diuji pada kecepatan yang sama, yaitu $10 \mathrm{~km} / \mathrm{jam}(2,78 \mathrm{~m} / \mathrm{s})$. Namun pada kenyataannya, mobil akan melaju hingga kecepatan 
maksimal yang diizinkan, yaitu $50 \mathrm{~km} / \mathrm{jam}$. Maka dari itu diperlukan pengujian pada variasi kecepatan yang lain untuk mengetahui nilai $C_{D}$ yang dihasilkan pada desain modifikasi 2.

\subsection{Simulasi Modifikasi 2 dengan Variasi Kecepatan}

Desain modifikasi 2 akan disimulasikan dengan variasi kecepatan sebesar $25 \mathrm{~km} / \mathrm{jam}$ dan $50 \mathrm{~km} / \mathrm{jam}$. Meskipun berjalan pada kecepatan $50 \mathrm{~km} / \mathrm{jam}$ dapat menyebabkan borosnya penggunaan energi, namun tetap patut diuji untuk mengetahui karakter aliran udara pada kecepatan maksimal.

Tabel 5. Hasil Simulasi Desain Modifikasi 2 pada Variasi Kecepatan

\begin{tabular}{|c|c|c|c|c|c|}
\hline Desain & Kecepatan & Reynolds Number & $C_{D}$ Total & $C_{D}$ Pressure & $C_{D}$ Skin Friction \\
\hline \multirow{3}{*}{ Modifikasi 2} & $10 \mathrm{~km} / \mathrm{jam}$ & $503.801,39$ & 0,32251 & 0,27701904 & 0,04594592 \\
\hline & $25 \mathrm{~km} / \mathrm{jam}$ & $1.257 .691,25$ & 0,29437 & 0,2536813 & 0,04068588 \\
\hline & $50 \mathrm{~km} / \mathrm{jam}$ & $2.517 .194,73$ & 0,26867 & 0,23225087 & 0,036416908 \\
\hline
\end{tabular}

Berdasarkan Tabel 5, dapat diketahui bahwa nilai $C_{D}$ berbanding terbalik dengan kecepatan aliran udara. Saat kecepatan semakin tinggi, nilai $C_{D}$ yang dihasilkan semakin rendah. Saat kecepatan bertambah, bilangan Reynolds dari sebuah aliran akan meningkat. Peningkatan bilangan Reynolds membuat jenis aliran berubah dari laminar menjadi turbulen. Dalam kasus simulasi ini, aliran udara sedang bertransisi dari laminar menjadi turbulen. Saat bilangan Reynolds meningkat, koefisien drag turun, ukuran wakes menjadi lebih kecil menandakan tertundanya fenomena separasi. Kondisi ini dapat dijelaskan sebagai berikut. Pada bagian belakang kendaraan (bagian sambungan antara kaca belakang dengan spoiler), tekanan mengalami peningkatan. Akibat adanya perbedaan tekanan, alirannya menjadi melambat, namun aliran pada lapisan batas kehilangan energi (momentum) karena gesekan dengan permukaan dan tidak memiliki energi yang cukup untuk mengatasi gaya tersebut, sehingga terjadi separasi. Kondisi tersebut terjadi pada aliran laminar. Aliran turbulen memiliki energi kinetik yang lebih besar dibandingkan dengan laminar, saat aliran turbulen memasuki daerah dengan tekanan yang lebih tinggi, aliran turbulen dapat melawan gaya pada area bertekanan tinggi tersebut akibat energi yang dimiliki oleh aliran. Sehingga aliran yang tadinya mengalami separasi dapat dilawan oleh aliran turbulen agar aliran tetap dapat menempel pada bodi kendaraan [14]. Berdasarkan fenomena ini, dapat dikatakan spoiler berfungsi dengan baik pada desain kendaraan. Kondisi ini juga didukung dengan kontur pada Gambar 10 kiri yang memiliki warna yang seragam (biru muda), di mana kontur ini merupakan kecepatan pengujian yang dilakukan pada desain modifikasi 2 , yaitu $6,94 \mathrm{~m} / \mathrm{s}(25 \mathrm{~km} / \mathrm{jam})$.

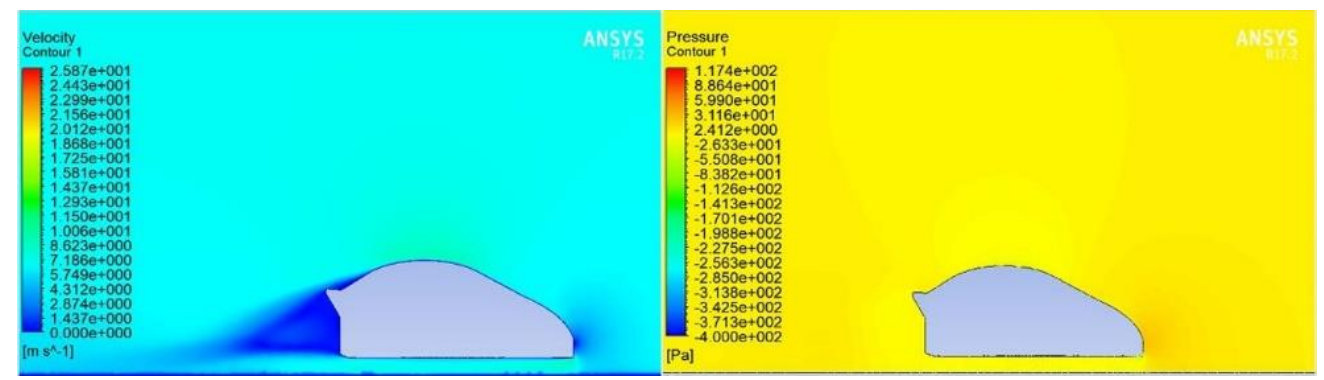

Gambar 10. Kontur Kecepatan dan Tekanan Desain Modifikasi 2 pada Kecepatan 25 km/jam

Faktor lain yang dapat menyebabkan turunnya nilai $C_{D}$ ialah turunnya pressure drag yang terjadi. Pressure drag sendiri merupakan gaya hambat yang disebabkan oleh adanya perubahan tekanan fluida yang bergerak pada suatu permukaan benda [15]. Pada Gambar 10 kanan bahwa tekanan yang terjadi pada permukaan mobil lebih seragam. Kondisi ini ditandai dengan warna kontur yang terlihat lebih seragam. Apabila tekanan yang terjadi sepanjang 
Glaudius Alexander Vajra dkk /Jurnal Rekayasa Mesin

p-ISSN: 1411-6863, e-ISSN: 2540-7678

Vol.16|No.2|210-217|Agustus|2021

permukaan mobil tidak terlalu berbeda jauh, maka nilai dari pressure drag akan menurun juga. Berdasarkan hasil simulasi, dapat diketahui bahwa rata-rata nilai $C_{D}$ desain modifikasi 2 pada variasi kecepatan ialah sebesar 0,295183. Nilai ini sudah masuk ke dalam batas yang diinginkan dalam tujuan penelitian ini, yaitu $<0,35$. Maka dari itu, desain modifikasi 2 merupakan desain yang akan digunakan untuk mengikuti kompetisi Kontes Mobil Hemat Energi.

\section{Kesimpulan}

Berdasarkan penelitian yang dilakukan menggunakan simulasi CFD, dapat disimpulkan bahwa desain bodi mobil hemat energi yang aerodinamis telah berhasil dirancang dengan nilai $C_{D}$ rata-rata sebesar 0,295183 pada desain modifikasi 2. Kemudian, bentuk frontal area bodi, sudut-sudut tajam pada bodi, bagian belakang bodi dan bentuk bagian bawah bodi merupakan parameter yang penting mempengaruhi nilai $C_{D}$ bodi. Penurunan nilai $C_{D}$ saat bertambahnya kecepatan disebabkan oleh energi kinetik pada aliran turbulen yang menunda terjadinya separasi aliran.

\section{Daftar Pustaka}

[1] Panitia KMHE 2019, “Regulasi Non-Teknis KMHE 2019,” 2019.

[2] "Kontes Mobil Hemat Energi Universitas Negeri Malang 2019," KMHE UM 2019. http://kmhe2019.um.ac.id/ (accessed Oct. 25, 2019).

[3] J. D. Anderson, Fundamental of Aerodynamics, 5th ed. New York: McGraw Hill, 2009.

[4] V. Udoewa and V. Kumar, "Computational Fluid Dynamics," 2012.

[5] S. R. Ahmed, G. Ramm, and G. Faltin, "Some Salient Features of The Time-Averaged Ground Vehicle Wake," SAE Trans., vol. 93, pp. 473-503, 1984.

[6] S. Banga, M. Zunaid, N. A. Ansari, S. Sharma, and R. S. Dungriyal, "CFD Simulation of Flow Around External Vehicle: Ahmed Body,” J. Mech. Civ. Eng. IOSR-JMCE, vol. 12, no. 4, pp. 87-94, 2015.

[7] Panitia KMHE 2019, "Regulasi Teknis KMHE 2019," 2019.

[8] M. Lanfrit, "Best Practices Guidelines for Handling Automotive External Aerodynamics with FLUENT," Fluent Deutschland GMBH, Germany, 2005.

[9] "dragNwake.pdf." Accessed: Mar. 24, 2021. [Online]. Available: http://brennen.caltech.edu/fluidbook/ externalflows/drag/dragNwake.pdf.

[10]D. Crolla, Automotive Engineering: Powertrain, Chassis System and Vehicle Body, 1st ed. USA: Elsevier, 2009.

[11] J. Katz, Race Car Aerodynamics: Designing for Speed, 2nd ed. Massachusetts: Bentley Publishers, 1995.

[12]F. M. White, Fluid mechanics, Eighth edition. New York, NY: McGraw-Hill Education, 2016.

[13] "Palaeocast | Palaeontology podcasts." https://www.palaeocast.com/hydrodynamics/ (accessed Nov. 23, 2020).

[14] "Drag of Blunt Bodies and Streamlined Bodies." https://www.princeton.edu/ asmits/Bicycle_web/blunt.html (accessed Nov. 23, 2020).

[15] Y. A. Cengel and J. M. Cimbala, Fluid Mechanics, 3rd ed. McGraw Hill, 2014. 